\title{
THE COMPARISON OF NINE-FACTOR MODEL AND DIAMOND MODEL: APPLICATION FOR THE CZECH REPUBLIC, SLOVAKIA AND HUNGARY
}

\author{
Pavlína Balcarová ${ }^{1}$ \\ ${ }^{1}$ Mendel University in Brno, Faculty of Business and Economics, Zemědělská 1, 61300 Brno \\ Email: balcarov@node.mendelu.cz
}

\begin{abstract}
The concept of macroeconomic competitiveness became a phenomenon during last decades. Its controversial nature arouses attention of many people all over the world. It is impossible to find a generally accepted definition of national competitiveness as well as the way how to measure and compare competitiveness of countries. This contribution will discuss two models dealing with macroeconomic competitiveness, the original Porter's diamond model and the nine-factor model. Besides methodology, differences and similarities of these models we will be interested in how results of both the models differ. The main goal of the contribution is the identification of differences between the diamond model and the nine-factor model. For practical application of both the models we chose three countries on different development level out of Central Europe: the Czech Republic, Slovakia and Hungary.
\end{abstract}

Keywords: comparison, diamond model, economic level, human factors, national competitiveness, nine-factor model, physical factors.

JEL classification: E29, F43, O32, O49

Doručeno redakci: 23.7.2012; Recenzováno: 19.3.2013; 6.4.2013; 19.4.2013; Schváleno k publikování: 11.9.2013

\section{Introduction}

The competitiveness of nations is a very controversial and discussed theme during last decades. It is not possible to find one and only definition of competitiveness on the macroeconomic level. Besides, some economists consider the concept of national competitiveness as nonsense. Thereafter it is very difficult to find a way, how to measure competitive ability of countries. We could mention many diverse definitions of competitiveness and find many indices to measure it. This contribution deals with one known approach to rating competitiveness of nations and its modification. The well-known approach is a model presented by Michael Porter called diamond model. Porter's name is probably rather connected with company strategy, but he also contributed to macroeconomic competitiveness theory.

In addition to the Porter's diamond model we will construct the nine-factor model. The ninefactor model is one of the modifications of the diamond model. It extends the original model and emphasizes the role of human factors in competitive advantage creating process. For this reason the nine-factor model should be more appropriate for less developed countries and should evaluate competitiveness of these countries more favourably. The original contribution lies in the application of both the models on Central Europe and comparison of the results in context of Central Europe. Heretofore the nine-factor model was rather applied to nonEuropean countries.

\section{Theoretical background}

The theoretical foundation of the nine-factor model lies in the work of Michael E. Porter. For this reason we will define macroeconomic competitiveness according to Porter's view as "the productivity with which a nation utilizes its human, capital and natural resources" (Porter, 2005). Porter (1998) weighed in the competitiveness theory with his diamond model, 
sometimes called competitiveness diamond. The diamond model interconnected microeconomic competitiveness with macroeconomic view. The competitiveness diamond is formed by four groups of determinants of a national competitive advantage: factor conditions, demand conditions, related and supporting industries and firm strategy, structure and rivalry. To reach and first of all to maintain the competitive advantage achievement in all parts of the diamond is necessary. Apart from this, it is important to realize that all parts of the diamond affect each other, as we can see in figure 1. Besides these internal factors there are two external factors, namely chance and government, which also shape competitiveness of the country. All together we can consider six groups of factors which shape competitiveness in the diamond model. (Please refer to M. E. Porter: The competitive advantage of nations (1998) for further details).

Figure 1: Original diamond model

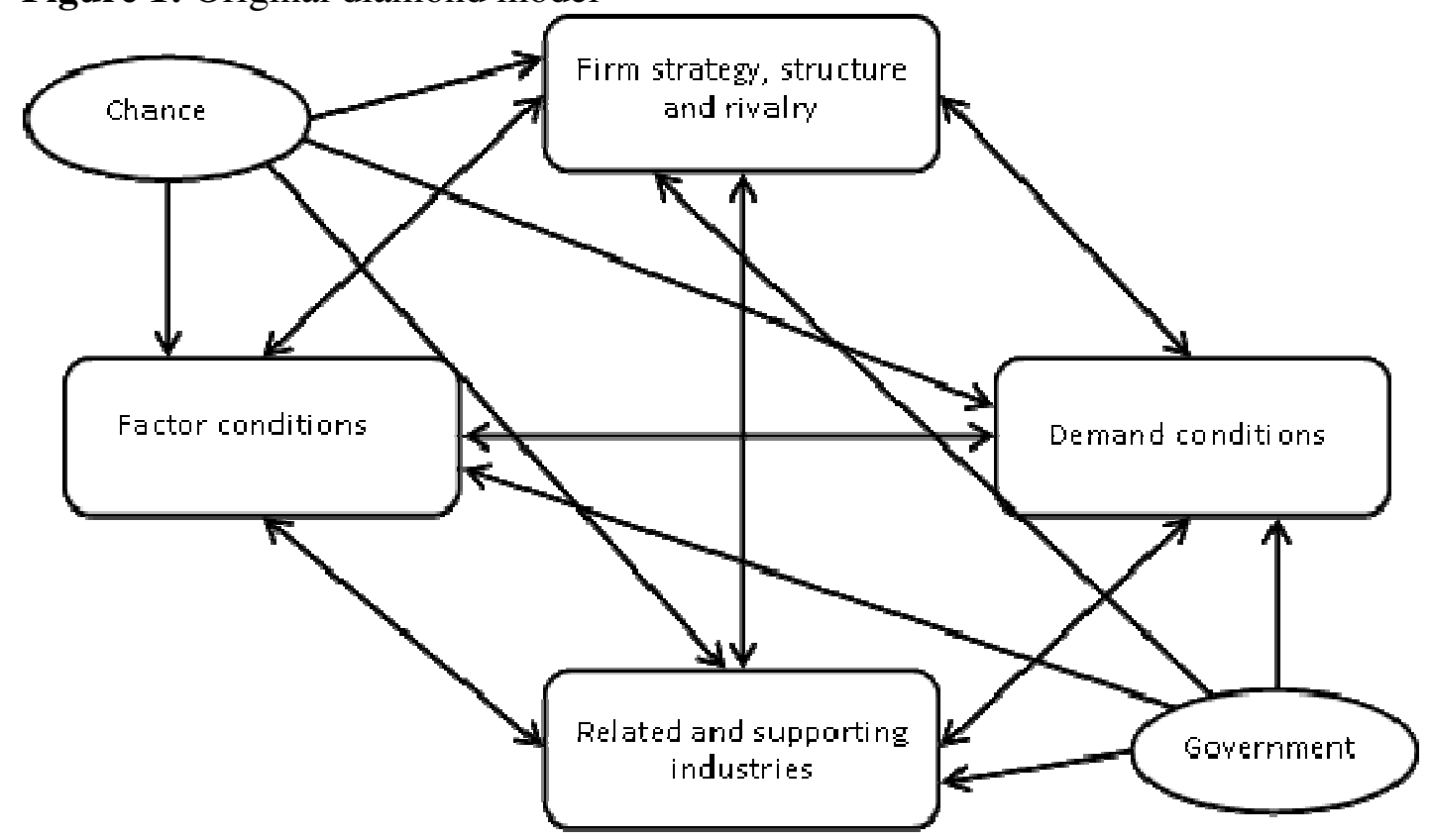

Source: Porter: The competitive advantage of nations (1998), own modification.

Porter's model represented a milestone in the macroeconomic competitiveness theory and provoke consequent discussion. On the one hand the critique of the concept of national competitiveness increased rapidly. The best known critic of national competitiveness concept is most likely Paul Krugman (1997). Krugman is set against the macroeconomic competitiveness concept and talks about dangerous obsession. But on the other hand, several advocates of the concept made use of the competitiveness diamond. One of the revised versions of the diamond model is the nine-factor model. Dong-Sung Cho (1994) built the nine-factor model as an extension of the competitiveness diamond. Cho argued that the competitiveness diamond is not feasible for less developed countries. In his nine-factor model Cho highlighted the role of human factors. Besides, he altered the structure of the model. Another model emerging out of the competitiveness diamond is the double diamond (Rugman, D'Cruz, 1993). The double diamond covers the same four groups of determinants of competitiveness as the diamond model, but these are divided into two parts, domestic and international diamond. The original Porter's model included only domestic diamond. This model is thus more suitable for open economies than the original diamond. A follow-up to the double diamond is the generalized double diamond model (Moon, Rugman, Verbeke, 1995). According to the authors, the diamond and double diamond model failed to define the 
competitiveness of small open economy. Porter's single diamond is fixed on large home based country, but in small open economies multinational activities are very important too. The generalized double diamond finally incorporated multinational activity as an endogenous variable of the model and is suitable primarily for small open economies (Balcarová, 2010). Cho, Moon and Kim (2006) connected through the two models mentioned above (nine-factor model and generalized double diamond) and created a complex model to evaluate competitiveness known as dual double diamond.

The nine-factor model includes nine groups of factors of competitive advantage as its name suggests. Eight of them are internal and only chance remains external factor of competitive advantage. The internal factors are grouped into two categories, physical and human factors. Four groups of competitiveness indicators belong to physical factors (endowed resources, domestic demand, business environment, related and supporting industries) and four groups to human factors (workers, entrepreneurs, politicians and bureaucrats, professional managers and engineers) of competitive advantage as it is obvious from figure 2 . The nine-factor model includes wider spectrum of factors than original diamond model. The human factors gained importance and represent the heart of the model. According to Cho (1994), actual right human factors put the model into the motion. Another essential difference against Porter's model is that the nine-factor model puts emphasis on the impact of human factors instead of interaction of individual parts of the model (Cho, Moon 2000).

Figure 2: The nine-factor model

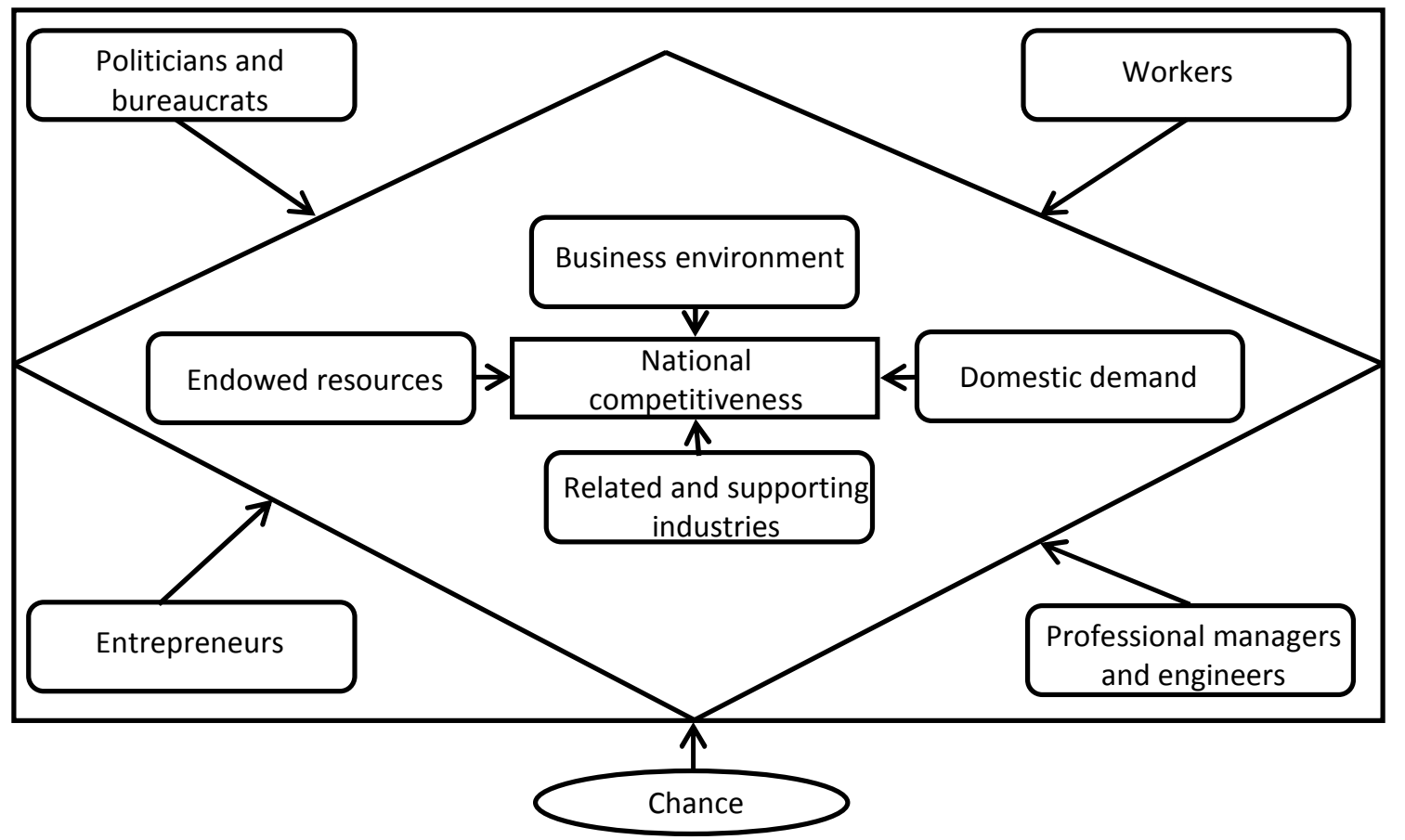

Source: Cho: A Dynamic approach to international competitiveness: The Case of Korea (1994), own modification.

The group of endowed resources includes mineral resources, agriculture, forestry, fishery and environmental resources. These factors have low influence in the diamond model (see Porter (1998)). Business environment is created by infrastructure level and quantity of barriers to start a business in the economy. In the diamond model infrastructure is included in group of related and supporting industries. The nine-factor model separates infrastructure between two groups of physical factors. Telecommunication infrastructure belongs to business environment and transportation is rather part of related and supporting industries. Apart from 
transportation this part of model includes financial, insurance and other service sector, raw materials or distribution networks. Domestic demand covers all indicators of size and quality of home demand. (Cho, 1994)

The really important part of the model is represented by a group of human factors. For the group of workers not only size of labour force is important, but in the first instance it is a quality of labour force, which is related to education level. Legislative activity and corruption level are the main factors of politicians and bureaucrats. Businesslike entrepreneurs influence the competitiveness of the economy positively and professional managers and engineers play crucial role in maintaining the acquired competitive advantage (Cho, 1994). It is interesting to notice that the government, which was external factor in diamond model, became internal in the nine-factor model.

\section{Aim and methodology}

The goal of the contribution is identification of differences between the diamond model and the nine-factor model. The differences are firstly discussed from the theoretical point of view. Subsequently the results of both the models are compared and discrepancies discussed. Three countries out of Central Europe on different development levels were chosen: the Czech Republic, Slovakia and Hungary. On the basis of this analysis we can check out the hypothesis that the nine-factor model is more suitable for less developed countries.

The development level can be expressed by GDP or GNP per capita. Both the indicators provide similar results. All data of GDP and GNP per capita draw on World Bank and are related to the year 2010. Cho (1994) divided countries into four groups according to their GNP per capita: less-developed countries, developing stage, semi-developed stage and developed stage. Hungary with GNP per capita 12860 USD belongs to semi-developed stage. This stage covers countries with GNP per capita between 3000 and 15000 USD. According to Cho related and supporting industries and entrepreneurs are key factors of competitiveness for countries in semi-developed stage. The Czech Republic and Slovakia range to developed stage, because their GNP per capita is higher than 15000 USD (in 2010 GNP per capita of Slovakia was 16840 USD and GNP per capita of the Czech Republic was 17890 USD). The competitive advantage of countries belonging to developed stage is created predominantly by factors of domestic demand and professional managers and engineers. (Cho, 1994)

Alternative classification of countries is provided by World Economic Forum (WEF) and is used in The Global Competitiveness Report, which is published by WEF every year. Countries are classified according to their GDP per capita into five stages of development: stage 1, transition from stage 1 to stage 2, stage 2, transition from stage 2 to stage 3 and stage 3. Hungary (GDP per capita is 12863 USD) and Slovakia (GDP per capita is 16071 USD) belong to transition stage between stage 2 a stage 3 . Countries in this stage are characterized by GDP per capita $9000-17000$ USD. It is obvious that Slovakia is much closer to the third stage of development. The Czech Republic with GDP per capita 18254 USD belongs to the third stage. Again different factors create competitive advantage on different development levels. Stage 2 is thus called efficiency driven and stage 3 is labelled innovation driven. (For more details about individual stages and factors of competitiveness please refer to WEF (2012)).

Both of these classifications provide us similar results, the Czech Republic belongs to the most developed stage in both the cases and contrariwise Hungary falls behind. Thus we can 
compare the results of diamond model and nine-factor model on case of countries out of the same region but on different levels of development.

The key issue is the choice of the variables for both the models. It is obvious that the variables choice influences the results considerably. The original Porter's model is formed by four groups of competitiveness determinants. In each category we chose a few indicators which shape the diamond model according to the author. It was not a purpose to construct a complex model including a wide range of variables. We just need to create a meaningful model to compare it with another model. All variables of diamond model are specified in table 1. It is a bit problematic to find all required data for the same time period. And what is more, it is impossible to find up-to-date data in some areas and that is why the analysed data series end in the year 2010. But it doesn't mind so much that the time series differ slightly, because we just want to compare results of two models.

The first group of factor conditions includes a wide range of determinants. But not all of them are sufficient to create and maintain the competitive advantage. Rather advanced and specialized factors are important than the basic and general ones (Porter, 1998). These factors are represented by three indicators of competitive advantage in our model: value added in industry, gross domestic expenditure on research and development (R\&D) and number of researchers in research and development (R\&D). In case of demand conditions not only the size of demand is important. The major role in the competitive advantage creating process plays the sophistication of home demand. For this reason primarily final consumption expenditure, number of tertiary graduates, public expenditure on education and sales for innovative products encourage competitiveness from the demand side. It is especially difficult to specify and choose indicators which shape the third vertex of the diamond. We chose three indicators, which make supplier relations easier. All of them concern domestic transport and telecommunication infrastructure. These factors are a length of motorways and tracks and a number of mobile cellular subscriptions. The advantage created in the last part of diamond has an impact on the innovation activity of enterprises and the whole economy as well. This should express the last two factors of the diamond model: level of innovation expenditure of enterprises and innovation capacity index.

Table 1: Variables of the diamond model

\begin{tabular}{|cl|}
\hline $\begin{array}{c}\text { Factor } \\
\text { conditions }\end{array}$ & $\begin{array}{l}\text { Value added in industry (2008-2010, \% of GDP) } \\
\text { Gross domestic expenditure on R\&D (2008-2010, Euro per inhabitant) } \\
\text { Researchers in R\&D (2008-2010, per million inhabitants) }\end{array}$ \\
\hline $\begin{array}{c}\text { Demand } \\
\text { conditions }\end{array}$ & $\begin{array}{l}\text { Final consumption expenditure (2008-2010, Euro per inhabitant) } \\
\text { Tertiary graduates (2008-2010, per 1000 of population aged 20-29 years ) } \\
\text { Public expenditure on education (2008-2010, \% of GDP) } \\
\text { Sales for innovative products (2008, \% of total receipts) }\end{array}$ \\
\hline $\begin{array}{c}\text { Related and } \\
\text { supporting } \\
\text { industries }\end{array}$ & $\begin{array}{l}\text { Mobile cellular subscriptions (2008-2010, per 100 inhabitants) } \\
\text { Railway transport - length of tracks (2010, 2009 in case of Hungary, km per million }\end{array}$ \\
\hline $\begin{array}{c}\text { Firm strategy, } \\
\text { structure and } \\
\text { rivalry }\end{array}$ & Length of motorways (2010, 2009 in case of Hungary, km per million inhabitants) \\
\hline
\end{tabular}

Source: Eurostat, World Bank, OECD, The Innovation for Development Report, CZSO. 
Table 2: Variables of the nine-factor model

\begin{tabular}{|c|c|c|}
\hline \multirow{4}{*}{ 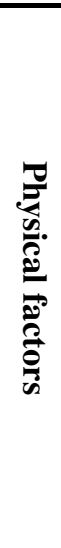 } & $\begin{array}{l}\text { Endowed } \\
\text { resources }\end{array}$ & $\begin{array}{l}\text { Renewable water resources }\left(2009,2007 \text { in case of Slovakia, } \mathrm{m}^{3} \text { per inhabitant }\right) \\
\text { Land area }\left(\mathrm{m}^{2} \text { per inhabitant }\right) \\
\text { Crude oils and petroleum products }(2009, \text { tonne per million inhab. })\end{array}$ \\
\hline & $\begin{array}{c}\text { Business } \\
\text { environment }\end{array}$ & $\begin{array}{l}\text { Internet users (2010, per } 100 \text { inhabitants) } \\
\text { Starting a business (days needed to start business) } \\
\text { Mobile cellular subscriptions (2008-2010, per } 100 \text { inhabitants) }\end{array}$ \\
\hline & Domestic demand & $\begin{array}{l}\text { Public expenditure on education (2008-2010, } \% \text { of GDP) } \\
\text { Final consumption expenditure ( } 2008-2010, \text { Euro per inhabitant) } \\
\text { Sales for innovative products (2008, } \% \text { of total receipts) }\end{array}$ \\
\hline & $\begin{array}{l}\text { Related \& } \\
\text { supporting } \\
\text { industries }\end{array}$ & $\begin{array}{l}\text { Railway transport - length of tracks }(2010,2009 \text { in case of Hungary, km per } \\
\text { million inhab.) } \\
\text { Length of motorways }(2010,2009 \text { in case of Hungary, km per million inhabitants) } \\
\text { Gross domestic expenditure on R\&D (2008-2010, Euro per inhab.) }\end{array}$ \\
\hline \multirow{4}{*}{ 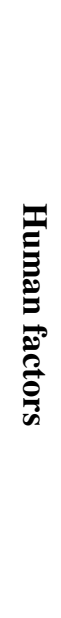 } & Workers & $\begin{array}{l}\text { Labour participation rate (2010, \% of total population over } 15 \text { years old) } \\
\text { Tertiary graduates }(2008-2010 \text {, per } 1000 \text { inhab. aged } 20-29 \text { years }) \\
\text { GDP per hour worked }(2009)\end{array}$ \\
\hline & $\begin{array}{c}\text { Politicians \& } \\
\text { bureaucrats }\end{array}$ & $\begin{array}{l}\text { Corruption perception index }(2009,0-\text { highest/10 - lowest corruption level }) \\
\text { GINI index }(2005,2009 \text { in case of Hungary, } 0 \text { - complete equality/100 - complete } \\
\text { inequality) }\end{array}$ \\
\hline & Entrepreneurs & Entrepreneurs (2008, \% of total employed) \\
\hline & $\begin{array}{l}\text { Professional } \\
\text { managers \& } \\
\text { engineers }\end{array}$ & IT specialists ( $2008, \%$ of total employed) \\
\hline
\end{tabular}

Source: Eurostat, World Bank, OECD, Doing Business, Transparency International, CZSO.

Table 2 displays a summary of variables which shape the nine-factor model. Some of them are similar to the variables included in the diamond model, but we attach more importance to the human factors and thus more detailed division of the indicators of competitiveness is necessary. For this reason some variables move to another group of competitiveness determinants (see Cho, Moon 2000). For example number of mobile cellular subscriptions belongs to related and supporting industries group in the diamond model and to the business environment factors in the nine-factor model. Again, it is not a complex overview of all the competitiveness determinants. We just need to build the nine-factor model for further comparison.

Endowed resources include primarily nature resources of the economy. In the model we will watch three basic nature resources: renewable water resources, land area and crude oil and petroleum products. The second group of physical factors indicates the telecommunication level and ease of doing business in the economy. We included a number of internet users, mobile cellular subscriptions and number of days needed to start a business specifically. The domestic demand has two main dimensions again: size and sophistication of home demand. Public expenditure on education and sales for innovative products quantify sophistication of home demand and the final consumption expenditure measures the size of home demand. The last part of physical factors is very similar to the corresponding part of the competitiveness diamond. But there are some small changes due to the different structure of the remaining parts of the model. Two indicators refer to transport infrastructure and they are supplemented with gross domestic expenditure on R\&D. 
The second group of indicators includes human factors of competitiveness. These are divided into four segments again. The category of workers is represented by three indicators - labour participation rate, tertiary graduates and GDP per hour worked, which should highlight the sophistication of workers. Not only quantity, but primarily quality of workers is significant for the competitiveness of nation. The second section of human factors concerns politicians and bureaucrats. To evaluate their activities we chose two indices - corruption perception index and GINI index. The first of them evaluates corruption level in the country and the second one evenness of income distribution. The last two indicators are measured by the share of entrepreneurs in an economy and the share of IT specialist in the labour market.

\section{Results and discussion}

After we chose variables for both the models and found the data, we can calculate competitiveness indices for the Czech Republic, Slovakia and Hungary. The competitiveness index is computed in a very simple way. We can demonstrate it on an example of factor conditions, i.e. the first part of the diamond model. Table 3 displays the data for the factor conditions.

Table 3: Factor conditions: variables and data

\begin{tabular}{|c|c|c|c|}
\hline & \multicolumn{1}{c|}{ Czech Republic } & Slovakia & Hungary \\
\cline { 2 - 4 } & \multicolumn{3}{|c|}{ Value added in industry } \\
Factor conditions & 36 & 36,3 & 30,3 \\
\cline { 2 - 4 } & \multicolumn{3}{|c|}{ Gross domestic expenditure on $R \& D$} \\
\cline { 2 - 4 } & 210,4 & \multicolumn{3}{|c|}{ Researchers in $R \& D$} & 108,1 \\
\hline & 2803,3 & 2510,3 & 1996,7 \\
\hline
\end{tabular}

Source: Eurostat, World Bank.

To compute the competitiveness index we use a simple method. The maximum value of each part of the diamond is 100 . If some part of diamond is specified by more indicators, then maximum value of each of them is 100 divided by number of indicators. For example the factor conditions are represented by three variables, thus each of them has weight of $1 / 3$. If the country does not achieve the maximum value, we compute its percentage share of the maximum value. For example the maximum value of value added in industry is $36.3 \%$, thus Slovakia achieved 100. Czech value added in industry is $36 \%$, i.e. $(36 / 36.3) * 100=99.2$. Analogically for Hungary, value added in industry is $30.3 \%$, thus $(30.3 / 36.3)^{*} 100=83.5$. Then in case of the factor conditions the competitiveness indices are as follows:

Czech Republic: $\frac{1}{3} \cdot 99,2+\frac{1}{3} \cdot 100+\frac{1}{3} \cdot 100=99,7$

Slovakia: $\frac{1}{3} \cdot 100+\frac{1}{3} \cdot 30+\frac{1}{3} \cdot 89,6=73,2$

Hungary: $\frac{1}{3} \cdot 83,5+\frac{1}{3} \cdot 51,4+\frac{1}{3} \cdot 71,2=68,7$

Competitiveness indices for all parts of the diamond model are in table 4. The Czech Republic achieved markedly the best result in all the parts of diamond with the exception of related and supporting industries. But the difference between Czech Republic and Hungary is insignificant. The last line of the table is total competitiveness index of each country. It was computed as standard arithmetic mean. The lowest value of competitiveness index was achieved by Slovakia and it is thus the least competitive country according to the diamond model. 
Table 4: - Diamond model: competitiveness index

\begin{tabular}{|c|c|c|c|}
\hline & Czech Republic & Slovakia & Hungary \\
\hline Factor conditions & 99,7 & 73,2 & 68,7 \\
\hline Demand conditions & 89,9 & 88,2 & 79,6 \\
\hline Related and supporting industries & 85 & 62,2 & 85,5 \\
\hline Firm strategy, structure and rivalry & 100 & 76,8 & 90,9 \\
\hline Total & 93,7 & 75,1 & 81,2 \\
\hline
\end{tabular}

Source: Eurostat, World Bank, OECD, The Innovation for Development Report, CZSO.

In the same way we compute the competitiveness indices for the nine-factor model, the results are displayed in table 5. If we have a look at the first part of the nine-factor model, i.e. physical factors, the Czech Republic loses in endowed resources and business environment categories. All in all, the worst results in the area of physical factors, has Slovakia. The leading position in the first part of the nine-factor model was achieved by Hungary which reached the most balanced results in all areas of physical factors of competitiveness. There are significant differences in the results among individual countries, which certainly influenced results of computed competitiveness index.

On the contrary, the competitive advantage in the human factors of competitiveness area in Hungary is poor in comparison with two other countries. Hungary achieved poor results especially in workers, entrepreneurs and professional managers and engineer's realm. The Czech Republic achieved a competitive advantage in the last two categories, namely entrepreneurs and professional managers and engineers. Generally the Czech Republic and Slovakia gain competitive advantage rather in the human factors and lose in the physical factors. Contrariwise Hungary's competitive advantage lies in the physical factors, but Hungary has a good initial position also in the human factors, its loss is not too big. Apart from that the differences among individual countries are much smaller than in case of the physical factors and thus the computed values are more smoothed. 
Table 5: Nine-factor model: Competitiveness index

\begin{tabular}{|c|c|c|c|}
\hline & Czech Republic & Slovakia & Hungary \\
\hline Endowed resources & 41,6 & 72,9 & 94,4 \\
\hline Business environment & 70,3 & 68,8 & 88,2 \\
\hline Domestic demand & 94,1 & 84,2 & 87,1 \\
\hline Related \& supporting industries & 85 & 45 & 71 \\
\hline Physical factors - total & 72,8 & 67,7 & 85,2 \\
\hline Workers & 86,3 & 100 & 73,3 \\
\hline Politicians \& bureaucrats & 95,6 & 91,6 & 100 \\
\hline Entrepreneurs & 100 & 89,7 & 75,5 \\
\hline Professional managers \& engineers & 100 & 81,8 & 72,7 \\
\hline Human factors - total & 95,5 & 90,8 & 80,4 \\
\hline Total & 84,2 & 79,3 & 82,8 \\
\hline
\end{tabular}

Source: Eurostat, World Bank, OECD, Doing Business, Transparency International, CZSO.

It is worth of noticing that the Czech Republic as well as Slovakia loses markedly in the physical factor criteria. Czech weakness is represented by endowed resources, so it should not be such disincentive for improving its competitiveness. The Czech Republic belongs to developed stage and the crucial role is played by factors of domestic demand and related and supporting industries respectively. The situation is much worse in Slovakia where the weak point is represented primarily by gross domestic expenditure on $R \& D$, which may signify a problem for future. Competitive advantage of Hungary grounds in the physical factors sphere where Hungary achieved the best results. On the other hand in human factors field the results of Hungary are a bit worse. Primarily Hungary loses in the factors of entrepreneurs and professional managers and engineers who are especially important for countries in semideveloped and developed stage respectively. This may entail holdout in future competitiveness improvement.

If we compare the two competitiveness indices, the first one computed on the basis of the diamond model and the second one set up on the basis of the nine-factor model, we can see several differences. It is not a purpose now to compare competitiveness of individual countries. Other competitiveness indices are more comprehensive (for example the Global competitiveness index by WEF mentioned above) and more suitable to evaluate competitiveness of the country. We are just interested in how the position of the single country changed when we compare the diamond model and the nine-factor model. As we can see, the results are much more balanced in case of the nine-factor model. The differences among individual countries are in case of the nine-factor model much smaller. The hypothesis 
thus cannot be declined. According to our results the nine-factor model provides better results for less developed countries than the diamond model.

\section{Conclusion}

The nine-factor model should be more suitable for less developed countries than the original Porter's diamond model. This hypothesis was confirmed in case of our three countries. The less developed countries (according to their GDP per capita level), e.g. Hungary and Slovakia achieved markedly better results when compared with the Czech Republic than in case of the diamond model. On the contrary the competitiveness ability of the Czech Republic worsened. But it must be taken into consideration that the choice of the variables for both the models has significant influence on our results. The variables choice and data availability are usually the most common problem of many competitiveness indices. Apart from that, value of competitiveness index for every country is affected by the results of other countries, which is given by used methodology of index calculation.

We can compare the results with other well-known competitiveness rankings. Our results correspond to IPS (Institute for Industrial Policy Studies) National Competitiveness ranking relatively well. Their national competitiveness research use methodology of the dual double diamond, which has lots in common with the nine-factor model. According to IPS Hungary is more competitive than the Czech Republic, Slovakia is not included. But if we look at another well-known ranking, Global competitiveness index, which is published by WEF, we get wholly different results. The Czech Republic has an advantage before the two other countries, Slovakia is in the middle and Hungary loses. The methodology used by WEF seems to be more appropriate to developed countries. It is thus obvious, that it is possible to construct the competitiveness index tailored to the country/group of countries needs. The results of different indices can thereafter markedly differ.

\section{References}

[1] BALCAROVÁ, P., 2010. The generalized double diamond model - application for Czech Republic and Slovakia. 2nd International PHD Students Conference, Brno: Masarykova univerzita.

[2] CHO, D. S., 1994. A dynamic approach to international competitiveness: The Case of Korea. Journal of Far Eastern Business.

[3] CHO, D. S. and H. C. MOON, 2000. From Adam Smith to Michael Porter: Evolution of competitiveness theory. Asia-Pacific business series - vol.2. ISBN 13978-981-02-4662-4.

[4] CHO, D. S., H. C. MOON and M. Y. KIM, 2006. Competitive strategy to enhance national competitiveness. In: Proceedings in Academy of international business 2006 annual meeting, Beijing, China.

[5] Czech statistical office (CZSO), Eurostat database, Sales for innovative products. [online]. [cit. 3rd June 2013]. Accessible from: http://apl.czso.cz/pll/eutab/html.h?ptabkod=tsdec340\#aV.

[6] European Business School. The Innovation for development report 2010-2011: Innovation as a driver of productivity and economic growth. [online]. [cit. 6th February 2012]. Accessible from: http://www.innovationfordevelopmentreport.org/index.html.

[7] Eurostat. Statistics. [online]. [cit. 30th May 2013]. Accessible from: http://epp.eurostat.ec.europa.eu/portal/page/portal/statistics/themes. 
[8] International institute for management development. World competitiveness yearbook. [online]. [cit. 12th January 2012]. Accessible from: http://www.imd.org/research/publications/wcy/index.cfm.

[9] KRUGMAN, P. R., 1997. Pop internationalism. London: The MIT Press. ISBN 0-26261133-3.

[10] MOON, H. C., A. M. RUGMAN and A. VERBEKE, 1995. The generalized double diamond approach to international competitiveness. In Alan M. Rugman, Julien Van Den Broec, Alain Verbeke (ed.) Beyond The Diamond (Research in Global Strategic Management, Volume 5), Emerald Group Publishing Limited, pp.97-114.

[11] MOON, H. C., A. M. RUGMAN and A. VERBEKE, 1998. A generalized double diamond approach to the global competitiveness of Korea and Singapore. International business review, volume 7 .

[12] OECD. Statistics. [online]. [cit. 2nd June 2013]. Accessible from: http://www.oecd.org/document/0,3746,en_2649_201185_46462759_1_1_1_1,00.html.

[13] PORTER, M. E., 1998. The competitive advantage of nations. New York: Free Press. ISBN 0684841479.

[14] PORTER, M. E., 2005. What is competitiveness. [online]. [cit. 14th December 2011]. Accessible from: http://www.iese.edu/en/ad/AnselmoRubiralta/Apuntes/Competitividad_en.html.

[15] RUGMAN, A. M. and R. J. D'CRUZ, 1993. The Double Diamond model of international competitiveness: The Canadian experience. Management international review 33(2). [online]. [cit. 10th November 2011]. Accessible from: http://www.jstor.org/pss/40228188.

[16] The Institute for industrial policy studies. National competitiveness research. [online]. [cit. 26th January 2012]. Accessible from: http://www.ips.or.kr/english/.

[17] Transparency international. Corruption perception index. [online]. [cit. 9th February 2012]. Accessible from: http://www.transparency.org/policy_research/surveys_indices/cpi.

[18] World Bank. Data. [online]. [cit. 1th June 2013]. Accessible from: http://data.worldbank.org/.

[19] World Bank. Doing business. Rankings. [online]. [cit. 9th February 2012]. Accessible from: http://www.doingbusiness.org/.

[20] World Economic Forum. The Global competitiveness report. [online]. [cit. 15th May 2012]. Accessible from: http://www.weforum.org/reports.

[21] World Economic Forum. The Global competitiveness report 2011-2012. 2012. [online]. [cit. 15th May 2012]. Accessible from: http://www3.weforum.org/docs/WEF_GCR_Report_2011-12.pdf 